\title{
Geothermal Power Generation
}

\author{
池上正俊
}

Masatoshi Ikegami

\begin{abstract}
This paper is concerned with the principle and the mechanism of geothermal power genera tion, as well as the brief history and the present situation of geothermal energy utilization. The history of geothermal power generation dates from 1904 when a $0.5 \mathrm{~kW}$ unit was operat ed on geothermal steam in Larderello, Italy. Some 90 years have passed since then, and it can be said that the technology for generating electric power using geothermal energy stably and economically over a long period of time has been established during the past decade. At the present time, geothermal power generation accounts for only less than $1 \%$ of the total electric power consumption in the world but it is conducted in 18 countries of the world in cluding Japan. Geothermal power generation is expected to develop more and more in fu ture as clean, purely domestic energy source acceptable to the environments of the earth.
\end{abstract}

\section{1. まえがき}

地熱発電の歴史は、1904 年にイタリアのラルデレ 口地方で地熱蒸気により $0.5 \mathrm{~kW}$ の発電機を運転した ことに始まる。

以来、その歴史も 90 年近くなるが、地熱発電を長 期に渡り安定かつ経済的に行うための技術は、ここ 10数年の間に確立されたと言える。

現在、地熱発電は、石油代替エネルギーとして世界 の全消費電力の $1 \%$ 満たすにも至っていないが、日 本を始め世界の 18 ヶ国で行われており、今後增々の 発展が期待されている。

\section{2. 地熱エネルギー開発の意義}

地熱エネルギー開発の意義として、Fig.1に示す 3 点が挙げられる。

第 1 に、環境問題への対応である。

昨今、地球環境の保全・保護問題が各方面で話題之 なっている。
特に化石燃料の大量消費に起因する地球温暖化問題 や、酸性雨の問題が全世界的な環境問題としてとりざ たされており、有害物質の排出が極めて少ない、クリ ーンな新エネルギー(地熱、太陽、風力等)の開発・利 用が急務となっている。

その中でも地熱エネルギーは既に発電技術が確立し ており、かつ潜在的エネルギー資源量の膨大さを考慮 すれば、極めて有望なエネルギーである。

地熱発電により放出される $\mathrm{CO}_{2}$ 量の火力発電との 比較を、Fig.2に示す。

第2に、一次エネルギーの供給安定化である。

特に我国では、Table 1に示すように全エネルギー の輸入依存度が極めて高く、その供給構造が脆弱であ るため、一次エネルギーの多様化・安定化、即ちセキ ユリティの確保は重要な問題である。

我国における地熱エネルギーの一次エネルギーに占 める比率は約 $0.1 \%$ 之非常に小さいが、世界有数の火 山国として、豊富に保有する純国産の地熱エネルギー への期待は大きなものがある。

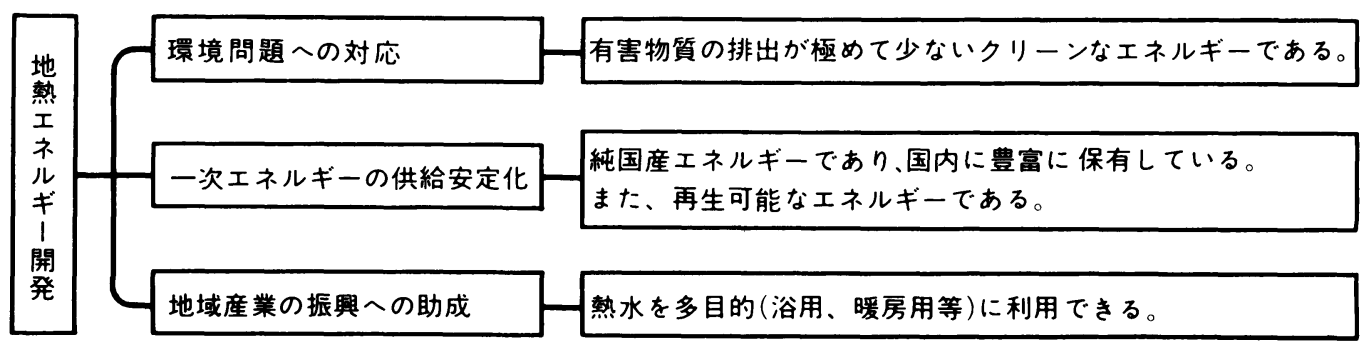

Fig.1. Merits of geothermal power generation.

三菱重工業(㑣)長崎造船所 Nagasaki Shipyard \& Machinery Works, Mitsubishi Heavy Industries, Ltd. 荳850- 91 長崎市飽の浦町 1 - 1 1 - 1 Akunoura, Nagasaki 850 - 91 
第3に、地域産業の振興への助成である。

地熱開発は発電のみに限らず、浴用、暖房、八ウス 園芸など、熱水の多目的利用により地域産業の振興に も大いに役立つことから、全国各地から地熱開発・地 熱調査を要望する声も多い。

\section{3. 地熱発電の現状}

地熱発電所は、世界で 253 プラントが建設され、総 発電容量も $6500 \mathrm{MW}$ を越えるまでになっている。 Fig.3に世界の地熱発電量の伸びを、Table 2 に国別 地熱発電設備容量を示す。

我国では、現在 10 地域 13 発電所 (試験プラントを 含めると 15 発電所) で地熱発電が行われており、その 発電容量は $283.8 \mathrm{MW}$ で世界第 7 位の地熱大国となっ ている。

Table 3に、我国の地熱発電所一覧を示す。またそ

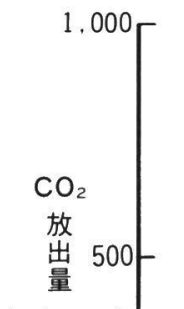

$(\mathrm{g} / \mathrm{kWh})$
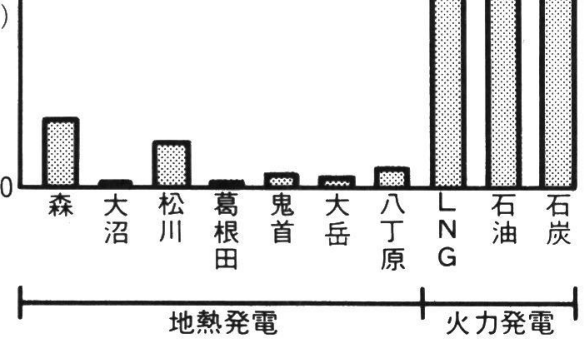

Fig.2. Comparison of $\mathrm{CO}_{2}$ emission between geothermal power generation and fossil pow er generation.

\begin{tabular}{|c|c|c|}
\hline \multirow{2}{*}{} & $\begin{array}{c}\text { 全エネルギーの } \\
\text { 輸入依存度 }\end{array}$ & $\begin{array}{c}\text { 石 油 の } \\
\text { 輸入依存度 }\end{array}$ \\
\hline (1986年) & $(1986$ 年) \\
\hline 日 本 & $80.1 \%$ & $99.6 \%$ \\
\hline 西 独 & $52.3 \%$ & $95.2 \%$ \\
\hline 英 & $\Delta 19.4 \%$ & $\Delta 69.4 \%$ \\
\hline 仏 & $55.6 \%$ & $95.9 \%$ \\
\hline 伊 & $79.3 \%$ & $96.9 \%$ \\
\hline 加 & $\Delta 19.1 \%$ & $\Delta 22.7 \%$ \\
\hline 米 国 & $12.3 \%$ & $34.6 \%$ \\
\hline \multicolumn{2}{|r|}{} & $\Delta$ は輸出を示す。 \\
\hline
\end{tabular}

Table 1. Dependence on the primary energy to be imported in major countries.
の位置を、Fig.4に示す。

発電システムを見てみると、我国初の実用地熱発電 プラントである松川地熱発電所のみが天然過熱蒸気を 利用した発電プラントである他は、熱水を利用したシ ングルフラッシュまたはダブルフラッシュ方式の発電

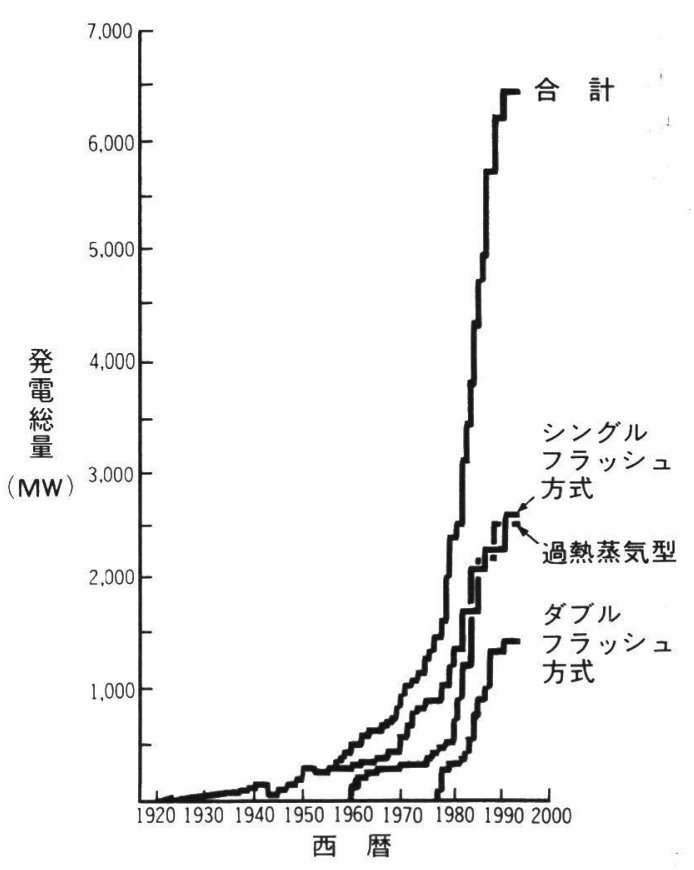

Fig.3. Increase of geothermal power generation in the world.

\begin{tabular}{|c|c|c|}
\hline 国 & ユニット数 & 発電容量 MW \\
\hline 国 & 71 & $2,905.4$ \\
\hline イリピン & 32 & $1,146.3$ \\
\hline メ キ シ コ & 32 & 820.6 \\
\hline イタ リ ア & 39 & 459.2 \\
\hline ニューシーランド & 16 & 300.6 \\
\hline インドネシア & 7 & 289.3 \\
\hline 日 本 & 15 & 285.3 \\
\hline エルサルパドル & 4 & 96.1 \\
\hline アイスランド & 7 & 71.3 \\
\hline ケ & 3 & 45.0 \\
\hline ト ル コ & 3 & 23.3 \\
\hline ニカラ グア & 1 & 20.0 \\
\hline ソ 連 & 4 & 15.6 \\
\hline 中 & 14 & 14.7 \\
\hline 湾 & 2 & 4.5 \\
\hline フ ラ ン ス & 1 & 4.2 \\
\hline ポルトガル & 1 & 3.0 \\
\hline ギリ シ & 1 & 2.0 \\
\hline 計 & 253 & $6,506.4$ \\
\hline
\end{tabular}

Table 2. Geothermal power generation capacities in each country. 


\section{プラントである。}

設備容量を見てみると、 $100 \mathrm{~kW} \sim 3000 \mathrm{~kW}$ のポー タブル型から $55000 \mathrm{~kW}$ の大容量機まで運転されてお り、その用途も、事業用、ホテル自家発電用之さまざ まである。

Fig.5に、日本最大の九州電力(侏)八丁原地熱発電所 $(55000 \mathrm{~kW} \times 2)$ の全景を示す。

本発電所は、世界で初めて、蒸気輸送方式に代わり 二相流体輸送方式を採用した、ダブルフラッシュ方式 の地熱発電所として昭和 52 年 6 月に運転を開始し、 平成 2 年 6 月には第 2 号機も運転を開始した。ダブル

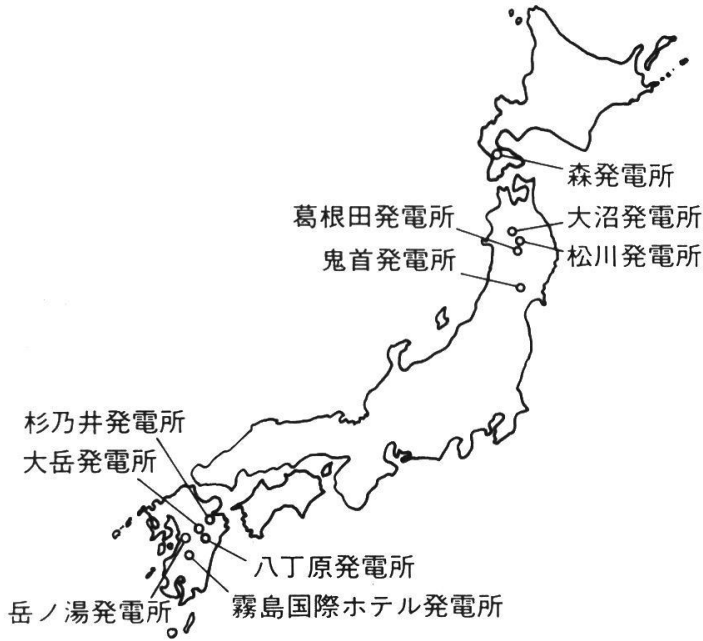

Fig.4. Locations of geothermal power plants in Japan.
フラッシュ方式の採用により、同一地熱熱水量に対し 約 $20 \%$ の出力増加を図っている。

一方、地熱発電所からの排熱水を近接の地域に供給 しているところが多く、Table 4 に示すように浴用、 八ウス園芸施設の暖房用として多目的に利用されてい る。

\section{4. 地熱発電の方式}

一般に、地球は地中深くなるに従って温度が上昇し、 深さ $30 \sim 50 \mathrm{~km}$ では約 $1000{ }^{\circ} \mathrm{C}$ 前後に達していると考 えられており、一つの大きな熱の眝蔵庫であるといえ

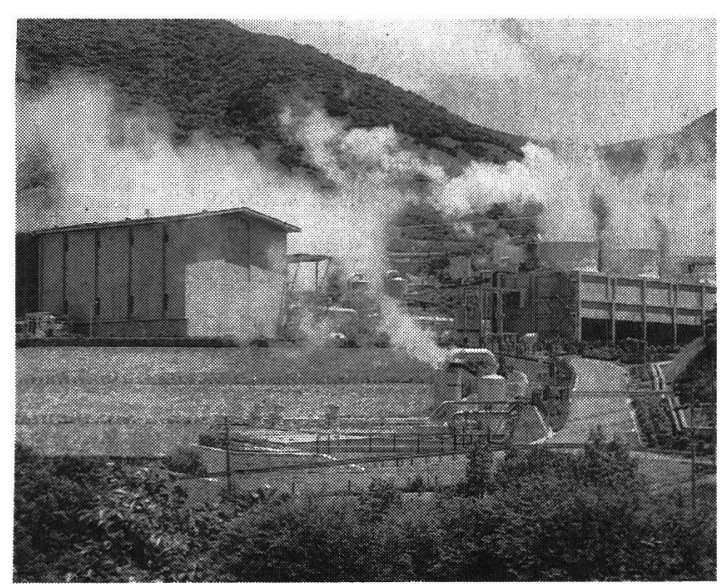

Fig.5. Hatchobaru power plant, Kyushu Electric Power Co., the largest geothermal power plant in Japan.
DS：過熱蒸気

$\mathrm{SF}$ : シングルフラッシュ DF : ダブルフラッシュ

\begin{tabular}{|c|c|c|c|c|c|c|c|c|c|c|}
\hline \multirow{2}{*}{ 発電所名 } & \multirow{2}{*}{ 所在地 } & \multirow{2}{*}{ 発電部門 } & \multirow{2}{*}{ 蒸気供給部門 } & \multirow{2}{*}{$\begin{array}{c}\text { エニット } \\
\text { (台) }\end{array}$} & \multirow{2}{*}{$\begin{array}{c}\begin{array}{c}\text { 設傮容量 } \\
(\mathrm{kW})\end{array}\end{array}$} & \multirow{2}{*}{$\begin{array}{c}\text { 铝可出力 } \\
(\mathrm{kW})\end{array}$} & \multirow{2}{*}{$\begin{array}{l}\text { 発電 } \\
\text { 方式 }\end{array}$} & \multicolumn{2}{|c|}{ 重電機メーカ } & \multirow{2}{*}{$\begin{array}{l}\text { 運転開始 } \\
\text { 年月 }\end{array}$} \\
\hline & & & & & & & & (タービン) & （発電機） & \\
\hline 松 & 岩手県松尾村 & 日本重化学工業侏 & 日本重化学工業怢 & 1 & 22,000 & 22,000 & DS & 侏東芝 & 侏東芝 & S41.10 \\
\hline 大 & 大分県九重町 & 九州電力蛛 & 九州電力怢 & 1 & 13,000 & 12,500 & SF & 三菱重工業㻝 & 侏東芝 & 542. 8 \\
\hline 沼 & 秋田県鹿角市 & 三菱金属侏 & 三菱金属株 & I & 10,000 & 8,600 & SF & 三菱重工業嫰 & 三菱電機梾 & S49. 6 \\
\hline 首 & 宮城県鳴子市 & 電源開発怢 & 電源開発梾 & 1 & 25,000 & 12,500 & SF & 川崎重工業侏 & 富士電機秢 & 550. 3 \\
\hline 八丁原 I号 & 大分蹎九重町 & 九州電力侏 & 九州電力怢 & 1 & 55.000 & 55,000 & $\mathrm{DF}$ & 三菱重工業㻝 & 三菱電機㖉 & S52. 6 \\
\hline 葛根田 I号 & 岩手県雨石町 & 東北電力怢 & 日本重化学工業(株) & 1 & 50,000 & 50.000 & SF & 制東芝 & 侏東芝 & S53. 5 \\
\hline 杉乃井 & 大分県別府市 & 橉彬乃井ホテル & 株杉乃井ホテル & 1 & 3,000 & 3.000 & $\mathrm{SF}$ & 三美重工業揦 & 三菱電機㤽 & S56. 8 \\
\hline 森 & 北海道森町 & 北海道電力侏 & 道南地篤エネルギー(侏) & 1 & 50.000 & 50,000 & DF & 侏東芝 & 侏東芝 & 557.11 \\
\hline 霧島国際ホテル1号 & 鹿児島 県牧園町 & 大和紀钼光 & 大和紡钼光味 & 1 & 100 & 100 & SF & 富士電機怢 & 富士電機挷 & S59. 2 \\
\hline 八丁原2号 & 大分県九重町 & 九州電力怢 & 九州電力蜥 & 1 & 55,000 & 55,000 & DF & 三菱重工業懒 & 三授電機拌 & $\mathrm{H} 2.6$ \\
\hline 霧島国際ホテル2号 & 鹿児岛県牧園町 & 大和紡钼光㸬 & 大和紡钼光虯 & 1 & 200 & 200 & SF & 三菱重工業侏 & 珠安川電機 & S63. 9 \\
\hline 霧島国際ホテル3号 & 鹿児蠆県牧園町 & 大和紡钼光 & 大和紡罆光蛛 & 1 & 300 & 300 & SF & 富土電機株 & 富士電機株 & S63. 9 \\
\hline 岳ノ湯 & 熊本県小国町 & 広瀬商事 & 広瀬商事侏 & 1 & 200 & 105 & SF & 三菱重工業㻝 & 安川電機 & H 3.10 \\
\hline
\end{tabular}

Table 3. Geothermal power plants in Japan. 
る。

特に火山や天然の噴気孔がある地熱地帯では、深さ 数 $\mathrm{km}$ の比較的浅いところに $1000{ }^{\circ} \mathrm{C}$ 前後のマグマ溜 りがあり、この熱が、地中に浸透した雨水などを加熱 して高温の熱水や蒸気を発生させ、地熱盯留層を形成 する。

地熱発電は、このように地下で生成した天然の蒸気 や熱水を人工的に取り出し、そのエネルギーでタービ ンを回して発電しようとするものである。

すなわち地熱発電では、火力発電におけるボイラの 役目を地球が果たしているといえる。

\section{1 地熱資源の種類}

地熱発電を行うための地下エネルギーが得られる地 熱資源としてFig.6に示すものがある。

\subsection{1 熱水卓越型地熱眝留層}

日本の温泉地のように、地上で熱水のみが得られる 地熱地帯は、世界に多く分布している。坑底(眝留層) 熱水温度が高く $\left(300^{\circ} \mathrm{C}\right.$ 前後 $) 、$ 熱水が自噴する際に坑 井途中でフラッシュして、地上で 2 ～10の熱水比(熱

\begin{tabular}{|c|c|c|}
\hline & 域 & 利角内容 \\
\hline & 森町 (北海道) & 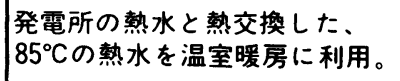 \\
\hline & $\begin{array}{l}\text { 松川(岩手県) } \\
\langle\text { 松川地熱発電所〉 }\end{array}$ & $\begin{array}{l}\text { 発電所の地熱水と熱交換した } \\
70^{\circ} \text { Cの熱水を旅館、別荘なとの } \\
\text { 暖房、浴用の他、60熱水を } \\
\text { 施設園芸に利用。 }\end{array}$ \\
\hline & $\begin{array}{l}\text { 大沼(秋田県) } \\
\text { 〈大沼地熱発電所〉 }\end{array}$ & $\begin{array}{l}\text { 発電所の蒸気と熱交換したた。 } \\
60^{\circ} \mathrm{C} の \text { 熱を水を旅館の浴用として } \\
\text { 利用。 }\end{array}$ \\
\hline 他 & $\begin{array}{l}\text { 大岳(大分県) } \\
\text { 〈大岳発電所〉 }\end{array}$ & $\begin{array}{l}\text { 発電所の地熱水と熱交換した、 } \\
80^{\circ} C \text { 熱水を住宅の暖房、浴用 } \\
\text { 及び設園芸に利用。 }\end{array}$ \\
\hline & $\begin{array}{l}\text { 八丁原(大分県) } \\
\langle 八 丁 \text { 原発電所〉 }\end{array}$ & $\begin{array}{l}\text { 発電所の地熱水と熱交換した、 } \\
8^{\circ} \mathrm{C} \text { の熱水を旅館、住宅の暖房、 } \\
\text { 浴用に利用。 }\end{array}$ \\
\hline & $\begin{array}{l}\text { 別府市 (大分県) } \\
\langle\text { 杉乃井ホテル } \\
\text { 杉乃井地熱発電所 }\end{array}$ & 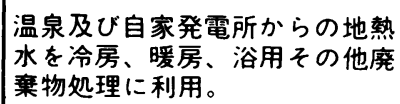 \\
\hline & $\begin{array}{l}\text { 牧園町(鹿児島県) } \\
\text { 霧島国際ホテル, } \\
\text { 地熱発電所 }\end{array}$ & $\begin{array}{l}\text { 温泉及び自家発電所からの熱水 } \\
\text { を冷房、暖房、浴用に利用。 }\end{array}$ \\
\hline & $\begin{array}{l}\mid \text { 電石町 (岩手県) } \\
\text { 〈葛根田地熱発電所〉 }\end{array}$ & \multirow{2}{*}{$\begin{array}{l}\text { 発電所の地熱水と熱交換した熱 } \\
\text { 水を住宅、公共施設等の暖房、 } \\
\text { 浴用をはじめ、エ業団地、施設 } \\
\text { 園芸、保冷庫、道路融雪等に } \\
\text { 利用。 }\end{array}$} \\
\hline & $\begin{array}{l}\text { 鹿角市(秋田県) } \\
\text { 〈大沼地熱 発 電所〉 }\end{array}$ & \\
\hline
\end{tabular}

Table 4. Utilization of geothermal energy.
水量/蒸気量)の流体が噴出してくる坑井を含めてい 世界の地熱地帯のほとんどがこの範囲入る。蒸気が付 帯して噴出する坑井はもちろんであるが、高温熱水の みしか噴出しない熱水坑井でも、経済的な発電が可能 なことは既に立証されている。

\subsection{2 蒸気卓越型地熱貯留層}

地熱発電は、地下から噴出する過熱地熱蒸気を使う ことから始まったが、このような蒸気卓越型地熱地域 では、蒸気を得るのが容易な上に蒸気供給設備が簡単 で斉むことから、極めて経済的な地熱発電ができる。

しかし、世界でもこのような条件の良い地熱地帯は 少なく、イタリアの他に米国のガイザー地区などごく 一部である。

\subsection{3 高温岩体 (Hot Dry Rock: HDR)}

地下深部の高温のマグマから加熱された地層が水の 侵入のない花崗岩などの場合、高温の地層は乾いた岩 体として存在することとなり、一般にこれを高温岩体 と呼ぶ。

この高温の岩体を $500 〜 600 \mathrm{~kg} / \mathrm{cm}^{2}$ の水圧によっ て破砕して人工のき裂を作り、そこに注水して熱エネ ルギーを取り出す技術は、開発の緒についたばかりで ある。

研究開発はアメリカ、イギリスおよび日本でも行わ れており、いずれも熱水の抽出に成功している。こ のようにして抽出された熱水を利用した発電方式を高 温岩体発電と呼び、一般的な試算によれば、我国で 7000 万 $\mathrm{kW}$ 程度の資源として評価できると言われてい る。

\subsection{4 深層熱水系}

従来の地熱貯留層は火山帯上の山間部に位置してい るが、これに対し平野を形成する堆積盆地には、比較 的温度の低い非火山性の深層熱水の存在が予想される。 堆積盆地の全層厚は数 $1000 \mathrm{~m}$ におよぶ地域が多く、 この地温勾配は $3 \sim 6{ }^{\circ} \mathrm{C} / 100 \mathrm{~m}$ に達している。

従って、地下 $2000 \mathrm{~m}$ 付近に閉じ込められた深層熱 水の温度は $60 \sim 120^{\circ} \mathrm{C}$ とな、地熱エネルギーとし ての利用が可能である。

\section{2 地熱発電方式の種類}

地熱井から噴出してくる流体の違いにより、 適用可能な地熱発電方式は次のように大別される。 (1) 過熱蒸気型

(2) 熱 水 型 T シングルフラッシュ

$$
\left[\begin{array}{l}
\text { ダブルフラッシュ } \\
\text { バイナリー }
\end{array}\right.
$$

各地熱発電方式のシステム図を、Fig.7に示す。 過熱蒸気型の発電方式としては、地下から噴出する 地熱蒸気を直接夕ービンへ送り発電を行うため、蒸気 
を分離するためのセパレータがないのが特徵である。

タービンの種類により、背圧式、復水式に分けられ る。

熱水型の発電方式としては、地下から噴出する地熱 流体から発電に利用する蒸気を分離するためのセパレ 一夕が設置され、蒸気を一回分離する方式をシングル フラッシュ方式、熱効率向上のため分離された熱水を 更に低圧でフラッシュさせて発電に利用する方式をダ ブルフラッシュ方式と呼ぶ。

また、地熱流体の温度が比較的低い場合には、低沸 点媒体との熱交换により熱回収を高めたバイナリ方式 が採用される。

地熱井の特性は各地域で異なっており、最も適した経 済的な発電方式が採用される。

過去に建設された地熱発電プラントは、イタリアの ラルデレロ地区や米国のガイザー地区のように過熱蒸 気型から始まったが、最近では熱水型の伸びが大きく シングルフラッシュ方式およびダブルフラッシュ方式 を合わせて全体の $1 / 2$ を超えている。

\section{5. 地熱発電のしくみ}

地熱発電は、地下 $1 \sim 2 \mathrm{~km}$ にある地熱眝留層から 蒸気・熱水を取り出し、その蒸気により直接タービン を回し発電する。

Fig.8に、地熱発電のしくみを示す。

蒸気井により地下眝留層から噴出した流体 (蒸気熱 水混合流) は、坑口に設置されたセパレータにより蒸 気と熱水に分離される。

Fig.9に、サイクロン式セパレータの構造図を示す。 分離された蒸気はタービンへ送られて発電に利用さ れ、セパレータより排出される廃熱水は、資源の確保 および環境対策上、還元井により地下還元される。

セパレータからの低圧（通常 $4 \sim 5 \mathrm{~kg} / \mathrm{cm}^{2} \mathrm{~g}$ ) の蒸 気は、蒸気輸送管により坑口から発電所内に輸送され、 タービンへ導かれる。

Fig.10に、複流復水式タービンの断面図を示す。 タービンの中央部に導かれた蒸気は、左右に分かれて 低圧 (真空)まで膨張し、翼の植えられたタービンロ 一夕を回転させる。この回転力が連結された発電機口 ータを回転させて発電する。

タービンで低圧まで膨張した蒸気は復水器内で冷却 水之直接接触し、熱交換により频縮する。

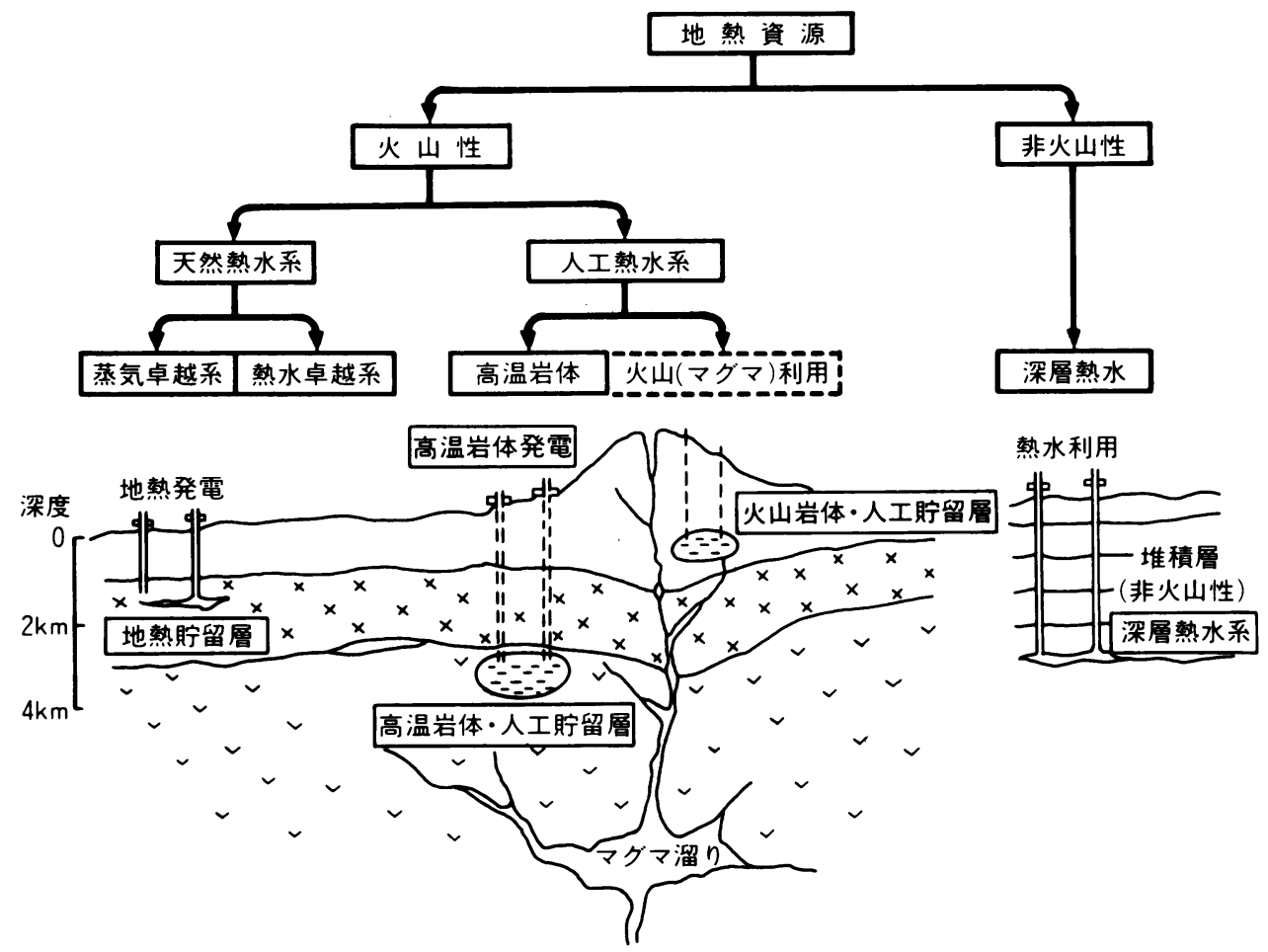

Fig.6. Geothermal resources. 
Fig.11に、復水器の構造図を示す。

復水器は、スプレージェット式主復水部とその両側に 配置されたトレイ式ガス冷却部から構成される。

復水器への冷却水は、冷却塔より大気圧と復水器器 内圧力 (真空) との差圧を利用して吸い込まれる。

地熱蒸気中には $\mathrm{CO}_{2}$ や $\mathrm{H}_{2} \mathrm{~S}$ などの不凝結性ガスが
含まれており、これ等は復水器ガス冷却部より、蒸気 エゼクタあるいは電動ブロワーなどのガス抽出器によ り抽出される。

復水器に溜った温水 (蒸気凝縮水および冷却水) は、 温水ポンプにより冷却塔へ送られる。

Fig.12に、対向流式機械通風冷却塔の構造図を示

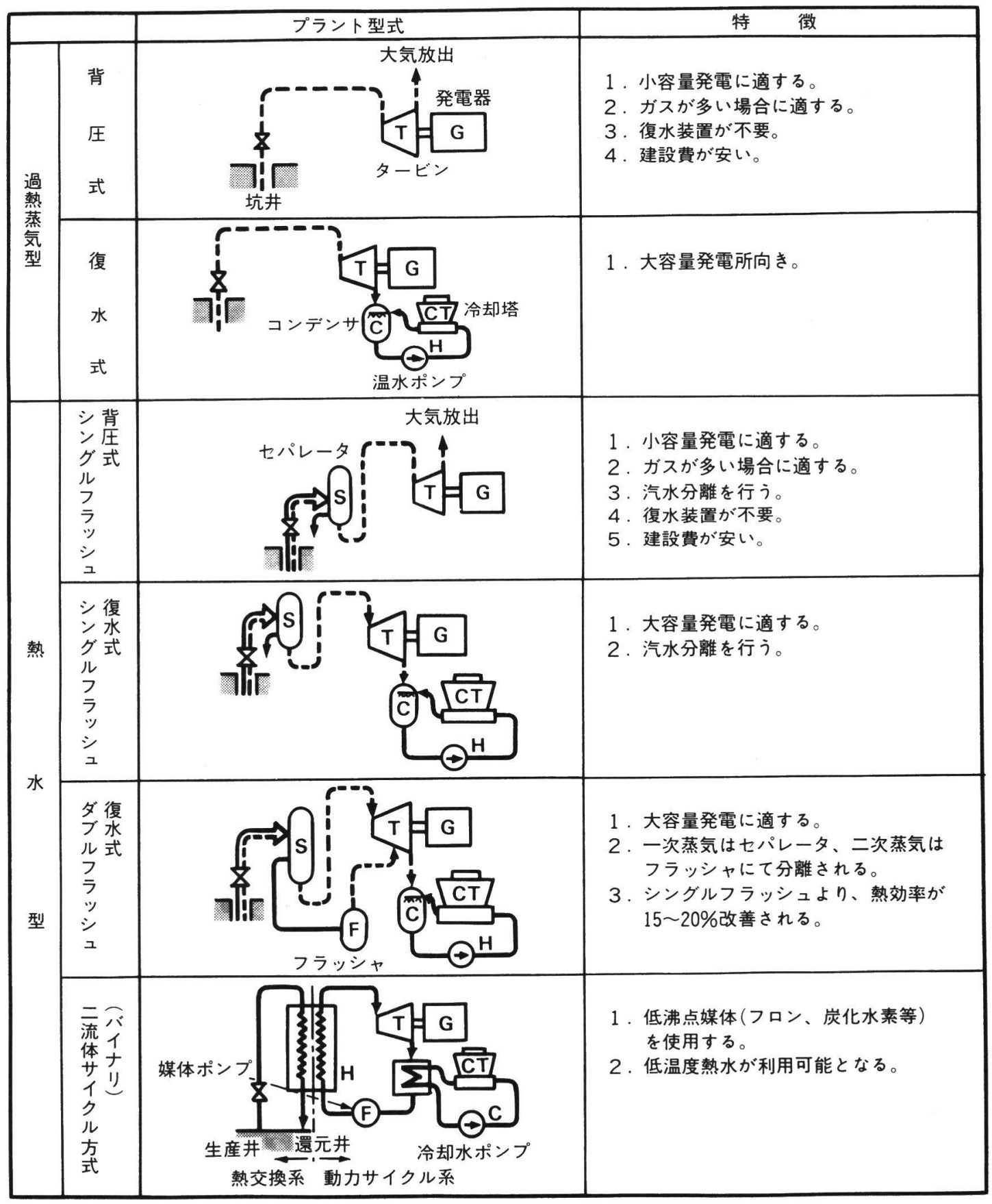

Fig.7. Type of geothermal power plant cycle. 
す。

冷却塔へ送られた温水は、吸い込まれた空気との熱 交換により冷やされ、再び冷却水となり復水器へ流入 する。通常、地熱発電所は山間部に立地され大量の冷 却水が入手できないため、冷却塔を介した再循環系統 を作り冷却水を得る。

このように、地熱発電のしくみは、構成機器数も少 なくシンプルなものとなっている。

\section{6.あとがき}

地熱発電は、我国の総発電量の $0.1 \%$ \%しか過ぎな いが、環境問題やエネルギーの安定供給の観点から今 後増々そのニーズが高まるものと予想される。近年は、 人工的に高温岩体中に高圧破砕によりき裂を作り、抽 熱するための研究開発も行われており、次世代の地熱 発電方法として期待されている。

今後とも、世の中のニーズに合った、経済的で信頼 性の高い地熱発電プラントの実現が重要である。

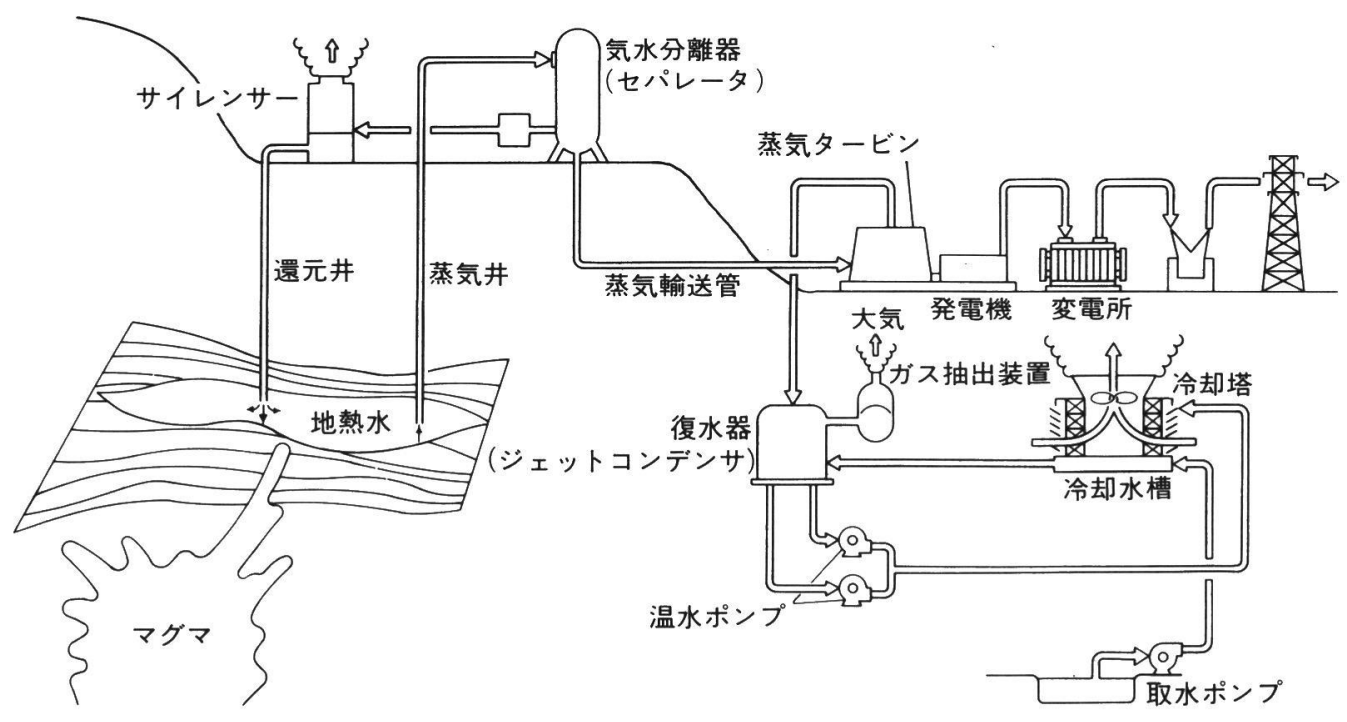

Fig.8. Geothermal power generation system.

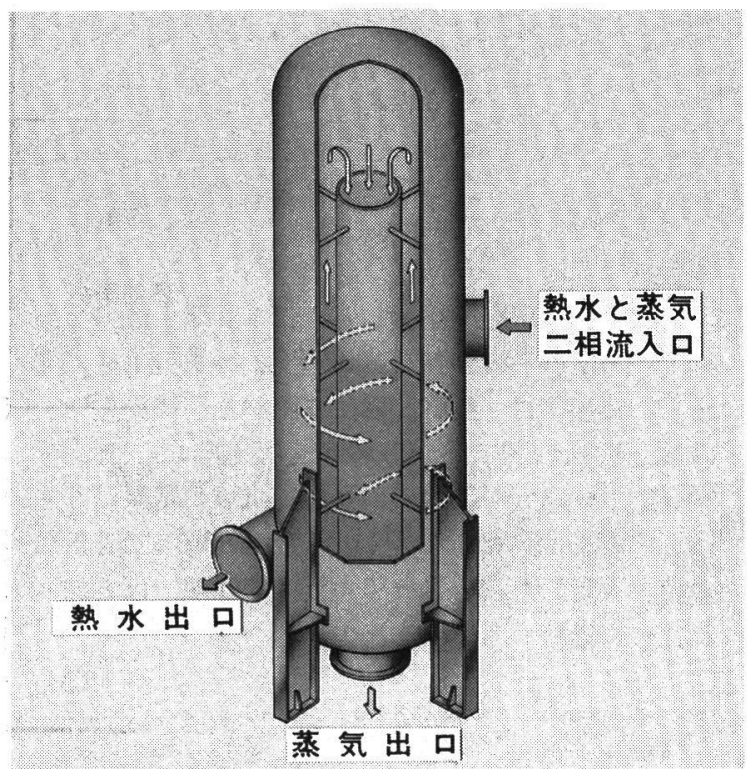

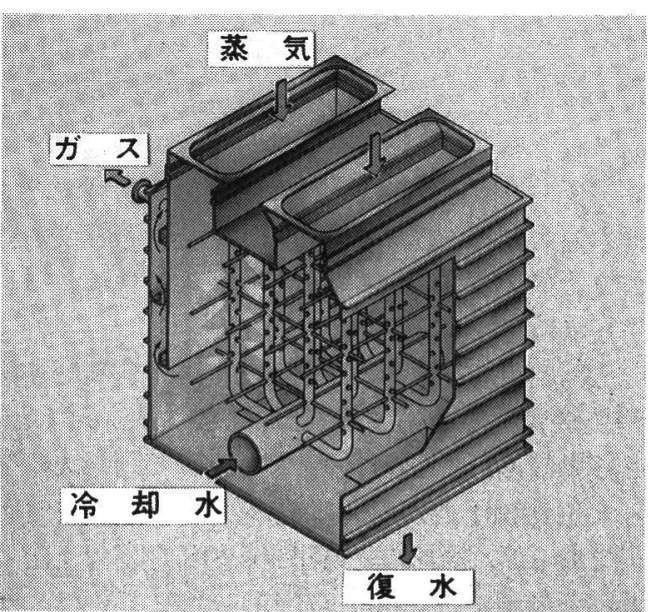

Fig.11. Jet condenser.

Fig.9. Separator. 


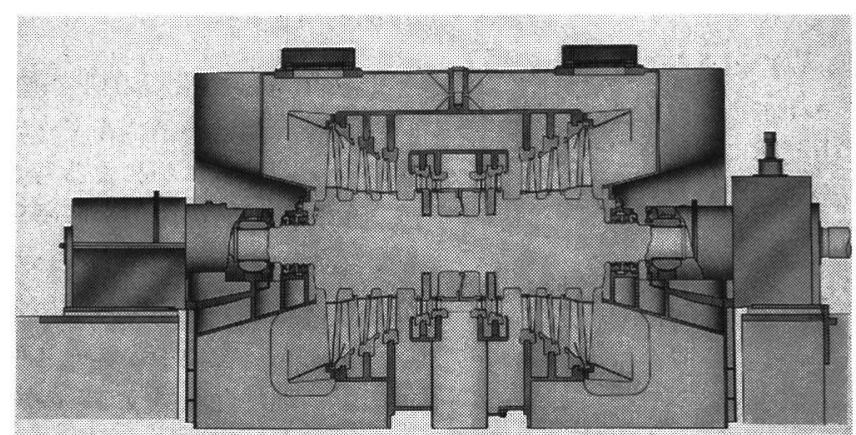

Fig.10. Turbine (double flow condensing type).

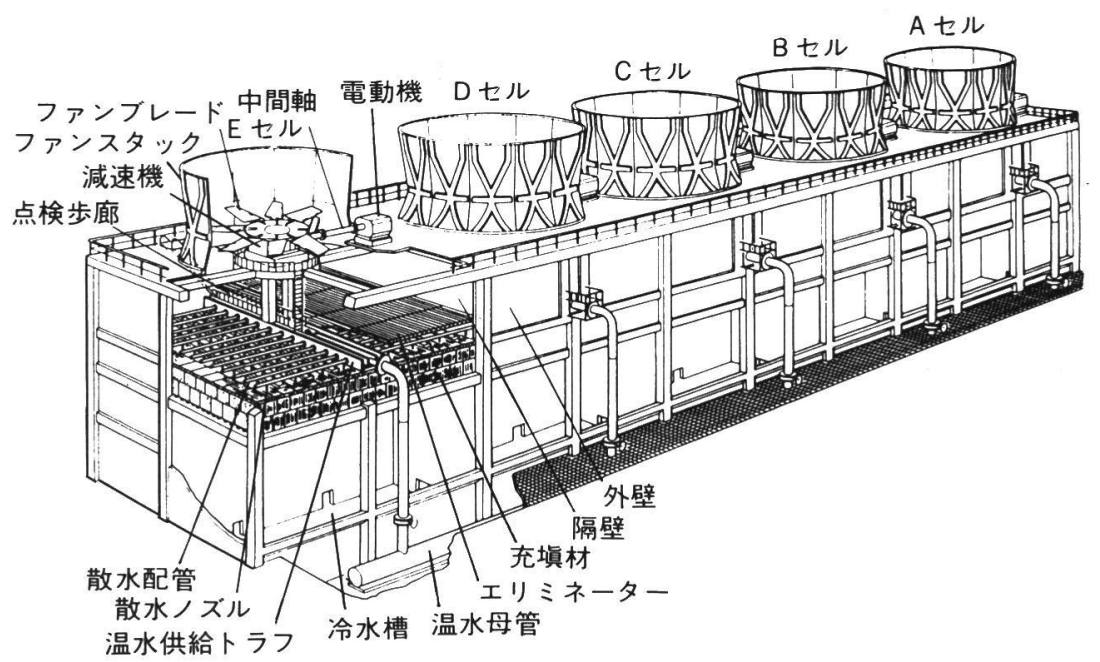

Fig.12. Cooling tower.

\section{圧力計の精度検定の試み}

高圧力を取扱う者にとって圧力計の精度や確度は 最も気になるところである。本学会でも『圧力計の 精度に関する研究・作業グループ』が昨年発足した ことは時宜を得た企画である。

国際度量衡委員会の下部組織である質量関連量諮 問委員会の中圧力WGでは、Air - Piston Gauge を移動標準器として、英・米・仏・日で国際比較を行 った。比較圧力の範囲は $11 \sim 131 \mathrm{kPa}$ の大気圧近 傍であるが、本邦の計量研究所の標準器は上記の先 進国の標準器と $3 \mathrm{ppm}$ 以内で一致していたことが
報告されている。

また、計量研を中核として、日本計量士会の発案 で『圧力トレーサビリティ委員会』が昨年 6 月に発 足し、参加委員（長野計器、双葉測器、横河電気、 計量士会）の間で持回り検定を実施した。20, 40 , $60,80,100 \mathrm{kPa}$ の圧力で相互比較試験の結果は、す べての参加団体の標準器が、 $50 \mathrm{ppm}$ 以内で計量研 の値之一致した。今後は圧力範囲を順次広げて持回 り比較を継続するとのことである。 